\section{IJ§ER}

ISSN: 2149-5939
International Journal of Social Sciences and Education Research

Online, http://dergipark.gov.tr/ijsser

Volume: 3(2), 2017

\title{
6331 Sayılı Tarımda İş Sağlığı ve Güvenliği Kanunu tarımda çalışanlar için bir şey ifade eder mi?
}

Does Act No 6331 on occupational health and safety make impacts on agriculture?

\author{
Bülent Gülçubuk ${ }^{1}$
}

\begin{abstract}
Received Date: $01 / 01 / 2017$
Accepted Date: $01 / 02$ / 2017

$\ddot{O} z$

Tarımda çalışanlar tarımsal üretimin niteliklerinden dolayı çeşitli risklerle karşı karşıya kalmakta hatta diğer sektörlere göre bu riskler daha yoğun yaşanmaktadır. Bu durum, tarımın doğal koşullara bağlı olması, mevsimselliğin önemi, ücretsiz aile işgücünün yoğunluğu, eğitim düzeyinin düşük olmasl, gelir istikrarsızlı̆̆l gibi tarıma özgü birçok nedene bağlı olarak ortaya çıkmaktadır. Bu nedenle, sosyal güvenlik kavramı herkes için yaşamsal öneme sahip olmakla birlikte tarım sektörü ve bu sektörde faaliyet gösteren kişiler ve aileler için daha da önemli bir hal almaktadır. Türkiye'de de tarım sektöründe çalışanlar sosyal güvenlik sistemine entegre edilmeye çalışılan en son gruptur. Tarımda bazı iş alanlarında riskler oldukça fazla olup, en riskli işler grubunda nitelenmektedir. Bu nedenle iş̧̧i sağlı̆̆ına, iş güvenliğine yönelik tüm adımlar önemli olduğu kadar yaşamsaldır. Türkiye'de 2012 yılında yayınlanan 6331 sayll "İs Sağllğı ve Güvenliği Kanunu" çalışan sayısı bir ve daha fazla olmak üzere tüm sektörleri kapsamaktadır. Böylelikle tarım, orman ve su ürünleri gibi iç içe geçmiş sektörlere de hitap edilmeye başlanmıştır. Ancak bu kanunun tarım sektörüne uygulanmasında önemli zorluklar söz konusudur. Bunun başlıca nedeni ise tarımda kayıt dışılık ile kadın ve çocuk işgücü kullanımının fazlalığıdır. 2015 yılı verilerine göre, tarım sektöründe çalışanların \%80,9'u kayıt dışı çalışmaktadır. Bu oran erkeklerde \%69,7 iken, kadınlarda \%95'i bulmaktadır. Oysa tarım için \%80,9 olan kayıt dışılık oranı tarım dışı sektörlerde \%21'e düşmektedir. Bu durum şunu ortaya koymaktadır; tarımda çalışanlar sosyal güvenlik şemsiyesinin dışında, kayıt dışı ve iş sağlığı ve güvencesinden de yoksundur. İște bunlardan dolayı da 2012 yılında yayınlanan 6331 sayılı "İs Sağlığı ve Güvenliği Kanunu” tarımdakiler için karşılık bulmuyor.
\end{abstract}

Anahtar sözcükler: $\dot{I}_{s ̧}$ sağllğı ve güvenliği, tarım, tarım işçiliğ $i$

\begin{abstract}
Those who work in the agricultural sector have various risks and even higher risks than other sectors due to its production circumstances. These risks result from different factors that are specific to agriculture. Some of these factors are: agriculture depends on natural conditions, the importance of seasonality, the density of unpaid family workforce, low education level, and the instability of income. Therefore, social security becomes more important for agricultural sector and those who work in this sector though it is vital for everyone. Agricultural sector workers are the last group that social security system tries to integrate in Turkey. There are high risks in some jobs in agricultural production and these risky jobs are classified under the highest risk group jobs. Thus, all measures of occupational health and safety are important as well as vital for agriculture. Act No 6331 on Occupational Health and Safety, which has come into force in 2012, involves all sectors with one and/or more workers. As a result, agriculture, forestry and aquaculture sectors, which are intermingled, have been also addressed. However, there are serious difficulties and obstacles to implement this law in the agricultural sector. The main reasons for these implementation problems are related to informal employment, and high level of women and children workforce. According to 2015 statistics 80,9\% of the agricultural workers are informally employed. It is 69,7\% for male workers while it increases up to $95 \%$ for female workers. The level of informal employment drops to $21 \%$ in other sectors. This fact reveals that agricultural workers stay out of the social security system and deprived of occupational health and safety. "Act No 6331 on Occupational Health and Safety" does not make impacts on agricultural working conditions.
\end{abstract}

Keywords: Occupational health and safety, agriculture, agriculture worker

${ }^{1}$ Prof. Dr., Ankara Üniversitesi Ziraat Fakültesi Tarım Ekonomisi Bölümü, Ankara, Türkiye gulcubuk@agri.ankara.edu.tr 
Gülçubuk, B. (2017). 6331 Sayılı Tarımda İş Sağlığı Ve Güvenliği Kanunu tarımda çalışanlar için bir şey ifade eder mi? International Journal of Social Sciences and Education Research, 3(2), 573-582.

\section{Giriş}

Tarım sektörü Türkiye'nin halen en nemli sektörlerindendir. Nüfusun \%20'sinden fazlası tarım ile uğraşmakta ve geçimlerini sağlamaktadır. Tarımda çalışanlar tarımsal üretimin niteliklerinden dolayı çeşitli risklerle karşı karşıya kalmakta hatta diğer sektörlere göre bu riskler daha yoğun yaşanmaktadır. Bu durum, tarımın doğal koşullara bağlı olması, mevsimselliğin önemi, ücretsiz aile işgücünün yoğunluğu, eğitim düzeyinin düşük olması, gelir istikrarsızlığı gibi tarıma özgü birçok nedene bağlı olarak ortaya çıkmaktadır. Bu nedenle, sosyal güvenlik kavramı herkes için yaşamsal öneme sahip olmakla birlikte tarım sektörü ve bu sektörde faaliyet gösteren kişiler ve aileler için daha da önemli bir hal almaktadır. Bununla birlikte, tüm Dünya'da olduğu gibi Türkiye'de de tarım sektöründe çalışan kesim sosyal güvenlik sistemine entegre edilmeye çalış1lan en son gruptur (SGK 2013). Türkiye ise gerek 1961, gerekse 1982 Anayasası ile "Herkes sosyal güvenlik hakkına sahiptir. Devlet, bu güvenliği sağlayacak gerekli önlemleri alır ve teşkilatı kurar" hükmüne yer vererek; sosyal güvenliği anayasal güvence altına almıştır. Sigortalıların sosyal güvenlik hakları 2006 yılındaki yasal düzenlemelere kadar 5 ayrı yasa ile düzenlenmiştir. Buna göre, hizmet akdiyle çalışanlar 506, kendi nam ve hesabına çalışanlar 1479, devlet memuru olarak çalışanlar 5434, tarımda hizmet akdiyle çalışanlar 2925, tarımda kendi nam ve hesabına çalışanlar ise 2926 sayılı kanunlara tabi olarak sosyal güvenlik kapsamına alınmaktaydı. Bu amaçla, sosyal güvenlik alanında reform olarak değerlendirilen ve 20 Mayıs 2006 tarih ve 5502 say1lı Kanunla kurulan Sosyal Güvenlik Kurumu (SGK); Türk sosyal sigorta rejiminin temel kurumları olan SSK (1945), Bağ-Kur (1971) ve Emekli Sandı̆̆ı'nın (1950) yanı sıra bankalar ve sigorta şirketlerinin vakıf statüsündeki sandıklarını bünyesinde birleştiren "tek çatı kurum" olmuştur. Bu Kanunla kurumsal anlamda birleşme sağlandıktan sonra, sosyal güvenlik kurumlarını sigortacılık anlamında da birleştirmek amacıyla 31.05.2006 tarihinde 5510 sayılı Sosyal Sigortalar ve Genel Sağlık Sigortası Kanunu kabul edilmiştir. Anılan Kanunun bazı maddeleri Anayasa Mahkemesi tarafından iptal edildiği için yürürlük tarihi 2008 yılına ertelenmiş ve ilgili yasal düzenleme, 1.10.2008 tarihinde yürürlüğe girmiştir (Işın vd. 2010, Alper vd. 2012).

Tarımda bazı iş alanlarında riskler oldukça fazla olup, en riskli işler grubunda nitelenmektedir. Bu nedenle iş̧̧i sağlığına, iş güvenliğine yönelik tüm adımlar önemli olduğu kadar yaşamsal olarak kabul edilmektedir. Türkiye'de 2012 yılında yayınlanan 6331 sayılı “İş Sağlığı ve Güvenliği Kanunu" çalışan sayısı bir ve daha fazla olmak üzere tüm sektörleri kapsamaktadır. Böylelikle tarım, orman ve su ürünleri gibi iç içe geçmiş sektörlere de hitap edilmeye başlanmıştır. Ancak bu kanunun tarımsal kesime uygulanmasında önemli zorluklar söz konusudur. Bunun başlica nedeni ise tarımda kayıt dışılık, kadın ve çocuk işgücü kullanımının fazlalığı ise bu kesimlerin sahipsizliğidir.

\section{Tarımsal işgücü ve kullanım nitelikleri}

Tarım sektöründe çalışanlar için en önemli sorun kayıt dışı çalışmaları ve bu nedenle de sosyal güvenlik uygulamalarının dışında kalmalarıdır. Bu durumda "tarımda iş sağlığı ve güvenliği "tarımda çalışanların çok büyük bir bölümü için fazla bir anlam taşımıyor. Bu konudaki verilere bakıldığında sonuçlar da kendiliğinden ortaya çıkmaktadır.

Türkiye İstatistik Kurumu 2015 Mayıs Ayı İşgücü İstatistiklerine göre istihdam oranı \%46,9, işgücüne katılma oranı ise \%51,7'dir.İstihdam edilenlerin sayısı 2015 yılı Mayıs döneminde, bir önceki yılın aynı dönemine göre 534 bin kişi artarak 27 milyon 72 bin kişi, istihdam oranı ise 0,2 puanlık artış ile \%46,9 oldu. Bu dönemde, tarım sektöründe çalışan sayısı 46 bin kişi azalırken, 
Gülçubuk, B. (2017). Does Act No 6331 on occupational health and safety make impacts on agriculture?

International Journal of Social Sciences and Education Research, 3(2), 573-582.

tarım dışı sektörlerde çalışan sayısı ise 580 bin kişi arttı. İstihdam edilenlerin \%21,3'ü tarım, \%20'si sanayi, \%7,2'si inşaat, \%51,5'i ise hizmetler sektöründe yer aldı. Önceki yılın aynı dönemi ile karşılaştırıldığında hizmet sektörünün istihdam edilenler içindeki payı 1 puan artarken, tarım sektörünün payı 0,6 puan, sanayi ve inşaat sektörünün payı 0,2 puan azaldı.Aynı dönemler için yapılan kıyaslamalara göre; erkeklerde işgücüne katılma oranı değişim göstermeyerek \% 71,8 , kadınlarda ise 1,1 puanlık artışla \%32,1 olarak gerçekleşti.

Çizelge 1. Tarım sektöründe çalışanların temel işgücü nitelikleri-TÜİK Şubat, 2015

\begin{tabular}{|c|c|c|c|c|c|c|c|c|c|}
\hline \multirow[b]{2}{*}{ İşteki durum } & \multicolumn{3}{|c|}{ Toplam } & \multicolumn{3}{|c|}{ Erkek } & \multicolumn{3}{|c|}{ Kadın } \\
\hline & $\begin{array}{l}\text { İstihdam } \\
\text { (000) }\end{array}$ & $\begin{array}{c}\text { Kayıt } \\
\text { dişı } \\
(000)\end{array}$ & $\begin{array}{c}\text { Kayıt } \\
\text { dışı } \\
\text { oranı } \\
\% \\
\end{array}$ & $\begin{array}{c}\text { İstihdam } \\
\text { (000) }\end{array}$ & $\begin{array}{c}\text { Kayıt } \\
\text { dişı } \\
(000)\end{array}$ & $\begin{array}{c}\text { Kayıt } \\
\text { dışı } \\
\text { oranı } \\
\% \\
\end{array}$ & $\begin{array}{l}\text { İstihdam } \\
\text { (000) }\end{array}$ & \begin{tabular}{|c} 
Kayıt \\
dışı \\
$(000)$
\end{tabular} & $\begin{array}{c}\text { Kayıt } \\
\text { dişı } \\
\text { oranı } \\
\% \\
\end{array}$ \\
\hline Toplam & 25454 & 8239 & 32,4 & 17896 & 4869 & 27,2 & 7559 & 3 370 & 44,6 \\
\hline $\begin{array}{l}\text { Ücretli veya yev- } \\
\text { miyeli }\end{array}$ & 17132 & 2948 & 17,2 & 12351 & 2012 & 16,3 & 4781 & 936 & 19,6 \\
\hline İșveren & 1103 & 141 & 12,8 & 1011 & 135 & 13,4 & 92 & 6 & 6,5 \\
\hline Kendi hesabına & 4471 & 2680 & 59,9 & 3771 & 2085 & 55,3 & 700 & 595 & 85,0 \\
\hline $\begin{array}{l}\text { Ücretsiz aile iş- } \\
\text { cisi }\end{array}$ & 2748 & 2470 & 89,9 & 763 & 637 & 83,5 & 1986 & 1833 & 92,3 \\
\hline Tarım & 4842 & 3917 & 80,9 & 2710 & 1890 & 69,7 & 2133 & 2027 & 95,0 \\
\hline $\begin{array}{l}\begin{array}{l}\text { Ücretli veya yev- } \\
\text { miyeli }\end{array} \\
\end{array}$ & 369 & 265 & 71,8 & 228 & 149 & 65,4 & 141 & 116 & 82,3 \\
\hline İşveren & 29 & 11 & 37,9 & 28 & 10 & 35,7 & 1 & - & - \\
\hline Kendi hesabına & 2184 & 1507 & 69,0 & 1947 & 1279 & 65,7 & 237 & 228 & 96,2 \\
\hline $\begin{array}{l}\text { Ücretsiz aile iş- } \\
\text { çisi }\end{array}$ & 2260 & 2134 & 94,4 & 507 & 452 & 89,2 & 1753 & 1683 & 96,0 \\
\hline Tarım dışı & 20612 & 4323 & 21,0 & 15186 & 2979 & 19,6 & 5426 & 1344 & 24,8 \\
\hline $\begin{array}{l}\text { Ücretli veya yev- } \\
\text { miyeli }\end{array}$ & 16763 & 2684 & 16,0 & 12123 & 1863 & 15,4 & 4640 & 821 & 17,7 \\
\hline İşveren & 1074 & 130 & 12,1 & 983 & 125 & 12,7 & 91 & 6 & 6,6 \\
\hline Kendi hesabına & 2287 & 1173 & 51,3 & 1824 & 806 & 44,2 & 463 & 367 & 79,3 \\
\hline $\begin{array}{l}\text { Ücretsiz aile iş- } \\
\text { cisi }\end{array}$ & 488 & 336 & 68,9 & 256 & 185 & 72,3 & 232 & 150 & 64,7 \\
\hline
\end{tabular}

Çizelge. 1 aslında birçok olguyu da net biçimde ortaya koymaktadır. Çizelge dikkatli incelendiğinde 2015 yılı verilerine göre, tarım sektöründe çalışanların \%80,9'u kayıt dışı çalışmaktadır. Bu oran erkeklerde \%69,7 iken, kadınlarda \%95'i bulmaktadır. Oysa tarım için \%80,9 olan oran tarım dış1 sektörlerde $\% 21$ 'e düşmektedir. Bu durum şunu ortaya koymaktadır; tarımda çalışanlar sosyal güvenlik şemsiyesinin dışında, kayıt dışı ve iş sağlığı ve güvencesinden de yoksundur. İşte bunlardan dolayı da 2012 yılında yayınlanan 6331 sayılı "Işs Sağllğı ve Güvenliği Kanunu” tarımdakiler için bir şey ifade etmiyor.

\section{Tarımın dezavantajlıları: Kadınlar ve çocuklar}

Kırsal alanda tarımda çalışanlar arasında kadın ve çocuk işgücü dezavantajlı çalışma grupları olarak kabul edilir. Bunlar hem kayıt dışı hem de evrensel çalışma ilkelerine uygun biçimde çalıştırılmadığı ve/veya çalıştırılması yasak olduğu için dikkati çekmektedir.

Kırsal kesimde kadının işgücüne katılım oranı, tarımda ücretsiz aile işçisi olarak çalışması nedeniyle yüksek olsa da Türkiye'de tarım istihdamındaki azalma, kadın istihdamının da giderek düşmesine yol açmaktadır. Tarımda çalışan kadınlar, tarım dışına çıktıklarında veya göç ettiklerinde işgücüne katılamamakta ya da zorluk çekmektedirler. İşücüne katılan kadınlar ise daha çok 
Gülçubuk, B. (2017). 6331 Sayılı Tarımda İş Sağlığı Ve Güvenliği Kanunu tarımda çalışanlar için bir şey ifade eder mi? International Journal of Social Sciences and Education Research, 3(2), 573-582.

statüsü düşük, kalifiye olmayan işlerde güvenceden yoksun bir biçimde çalışmaktadır. Bu ise kadının çalışma ve toplum hayatının dışında kalmasına neden olabilmektedir.

Tarımsal gelirlerin azalması, erkeklerin tarımı giderek terk etmesine ve böylece tarımın kadınlaşmasına yol açmıştır. Kadınlar kırsal alanda ailelerine sundukları bakım hizmetlerinin yanı sıra hem ev içinde üretim faaliyetlerini sürdürmekte hem de ev dışında tarımsal üretime katılmaktadır. Küçük ve orta büyüklükteki işletmelerde emek yoğun işleri çoğunlukla kadınlar üstlenmektedir ve iş yükleri genellikle erkeklerden fazladır. Ancak erkeklerin yaptıkları işler toplumsal olarak daha prestijli ve karşılığında daha fazla gelir getiren işlerdir. Kadınların yaptıkları işler daha çok ev eksenli emeğe dayanan mevsimlik, yarı zamanlı, ücretsiz işler olmaktadır. Bunlara bağlı olarak kadınların yaptıkları işlerden elde edilen ürünler -yiyecek, giyecek- çoğunlukla hemen tüketildikleri için ekonomik olarak bir değer ifade etmemektedir. (Gulçubuk ve Yasan, 2009)

İstihdamındaki azalışa rağmen tarım, kadınların hala en çok istihdam edildiği sektör olma özelliği sürdürmektedir. Kadınların kırsalda işgücüne katılım oranı kente göre daha yüksektir. TÜİK 2015 verilerine göre; toplam istihdamın yaklaş1k \%21,0'i tarımda yer alırken bu oran kadınlarda $\% 32$, erkeklerde ise $\% 15$ 'dir. Yani, tarımda kadınların istihdam edilme oranı erkeklerin istihdam edilme oranının yaklaşık 2,2 katıdır. Bu durum şunu ortaya çıkarmaktadır; kırsal alanda tarım dışında yaratılan istihdam alanları genelde erkeklere göre olmaktadır, tarım kırsaldaki kadınların kaderi olmaya devam etmektedir. Burada şunu da hemen belirtmek gerekir ki, tarımda çalışan kadınların \%80'ine yakını ücretsiz aile işgücü olarak çalışmaktadır.

Kırsal alanda çalışan kadınların büyük çoğunluğu yukarıda belirtildiği gibi, ücretsiz aile işçisi konumunda yer almaktadır. Kadın işgücü istihdamının arttırılması her şeyden önce ekonomik gelişme ile ilgili olup yeni yatırımların yapılmasını ve yeni iş sahalarının açılmasını gerektirmektedir. Kırsalda "işveren" olarak çalışan kadınların oranının düşüklüğü de burada dikkate değerdir. Bu durumda toplumda kadınların "girişimci" olarak hemen hemen hiç yer almadıklarının bir kanıtıdır. Burada önemle üzerinde durulması gereken önemli bir olgu da gerek çalışma hayatında gerekse toplumsal-kültürel hayatta işgücüne yoğun katılımı olan kırsaldaki kadının ihmalidir. Sosyo-politik ve ekonomik önlemlerin, politikaların üretilmesinde çoğunlukla kentteki kadın dikkate alınır, kırdaki kadına bakış ise "yoksun” bakış açısı olarak ortaya çıkmaktadır.

Kırsal alanda kadınlar sosyal güvenlikten yoksun ve en zor koşullarda çalışanlardır. Yoksulluk riskiyle ve dolayısıyla sosyal dışlanmayla en fazla karşı karşıya kalan kesim özellikle tarım sektörü ile geçici ve güvencesi olmayan işlerde çalışan, eğitimden yoksun bırakılan kadınlardır. Toplam nüfusun yarısını oluşturan kadınlar eğitim, ekonomi, ticaret ve genel olarak sosyal alanlarda çeşitli engellerle karşılaşmaktadırlar ve bu durum yoksulluğun da kadınlaşmasına neden olmaktadır. (Gulcubuk ve Yasan, 2009)

Çocuk iş̧̧iliği sadece Türkiye'nin değil hemen hemen tüm gelişmemiş ve gelişmekte olan ülkelerin önemli bir sorunudur. Milyonlarca çocuk; fiziksel, zihinsel, eğitsel, sosyal, duygusal ve kültürel gelişimlerine zarar veren ve ulusal yasalarla veya yasa dışı yollarla uluslararası normlara uygun olmayan koşullarda çalışmaktadır. Çocuk işçiliği sorunu ülkelerin; nüfus, eğitim düzeyi, ekonomik gelişme, istihdam ve genel kalkınma düzeyleriyle yakından ilgilidir.Dünya kamuoyu çocuk emeği istismarına karşı duyarlılı̆̆ını geliştirirken, çocuk işçiliğini hedef alan hareket de, hızı ve yoğunluğu açısından benzeri görülmemiş küresel bir dava haline gelmiştir. Bu, siyasal sınırları, dilleri, kültürleri ve manevi gelenekleri aşan bir hareket boyutunu almıştır. Sivil toplu- 
Gülçubuk, B. (2017). Does Act No 6331 on occupational health and safety make impacts on agriculture?

International Journal of Social Sciences and Education Research, 3(2), 573-582.

mun bütün kesimleri bir araya gelerek çalışma yaşamında çocuk sömürüsüne son verilmesi gerektiğini ilan etmişlerdir. Türkiye açısından da çocuk işçiliğine karşı önlem almak, çözüm üretmek, duyarlılık göstermek evrensel bir sorumluluk haline gelmiştir. Türkiye'de yaklaşık bir milyon çocuk iş̧̧iliğinin \%50'ye yakını tarımda gerçekleşmektedir. Tarım işçiliği çocukları en çok etkileyen sektörlerdendir. Tarımda çocuklara yönelik başlıca tehlikeler; güneşin altında veya soğuk rüzgârlı havalarda saatlerce çalışmak, yetersiz ve güvenli olmayan alet ve makineler, çalışılan tarladan gelen toz, aşırı sıcaklık değerlerine ve tehlikeli kimyasallara maruz kalma, kişisel koruyucu donanım olmaksızın çalışma, ağır yükler, tehlikeli hayvanlar, zehirli böcekler, yılanlar ve benzeridir. İşte bu durumlar çocuklar için de defacto bir durumdan dolayı mutlaka iş sağlığı ve güvenliğine yönelik önlemlerin alınmasını gerektirmektedir. Burada özlenen ise çocuk işçiliğinin tamamen kaldırılmasıdır.

\section{Riskli bir grup olarak mevsimlik tarım işçileri}

Mevsimlik gezici ve geçici tarım işçiliği, emek yoğun tarım üretim sürecinde karşımıza çıkan bir istihdam türüdür. Tarihi 60-70 yıl öncesine giden bu istihdam türü tamamıla enformel bir çalışma alanıdır. Kendilerine özgü bir çalışma yasası olmayan mevsimlik tarım işçileri çalışmaya dayalı birçok evrensel haktan mahrumdurlar daha doğru bu konuda varsa bilgilerden de yoksundurlar. Ne yazık ki Türkiye'de henüz mevsimlik tarım işçilerinin sayısına ilişkin resmi anlamda sağlıklı bir veri de bulunmamaktadır. Bu konuda yapılmış bazı araştırma bulgularına göre mevsimlik gezici ve geçici tarım işçisi sayısı 750.000-1.000.000 arasında değişmektedir. Enformel çalıştıkları ve de sayıları tam olarak bilinmemesi nedeniyle bu işçi grubu aynı zamanda sessizlerin sessizi kategorisinde olup adeta sorunları karşısında "sessiz çığlık" atmaktadır. Ana sorun bu işçilerimizin sesini duymak, duyarlı olmak, sorunlarına çözüm bulabilmektedir.

Gezici ve geçici mevsimlik tarım işçilerinin sayısı hakkında resmi bir veriden söz etmek zordur. Var olan bazı verilerin de doğruluğunu kabul etmek zor. Resmi verilere göre 300.000 civarında mevsimlik tarım işçisi var. Fakat tarımda gereksinim duyulan işgücü miktarı ile yapılan bazı akademik çalışmalara-araştırmalara göre ülkemizde 750.000-1.250.000 arasında mevsimlik gezici tarım işçisinin varlığından söz edilebilir. Gezici ve geçici tarım işçilerine ait resmi veriler bulunmadığı için bunların kayıtlılığı ve sosyal güvenlik durumları hakkında bilgi vermek zordur.

Kayıt dış1ık, örgütsüzlük, kamunun ilgisizliği, iş kaybı endişesi, yasaların uygulanmayışı ve de sahipsizlik hak aramayı tarım işçileri açısından imkânsız hale getiriyor. Özellikle mevsimlik gezici tarım işçiliği iş kazalarının/iş cinayetlerinin en çok olduğu iş kollarındandır. Bu konuda net bir veri bulunmamakla birlikte öncelikle trafik kazaları en çok gündeme gelen iş kazalarındandır. Fakat rahatlıkla tahmin edilebilecek bir şey var ki, çalışma ve barınma-yaşam koşullarının ağırlığından dolayı her yıl onlarca mevsimlik tarım işçisini kaybetmekteyiz. Bunlara yol açan unsurlar ise trafik kazaları, zehirlenme, yılan-akrep sokması, güneş çarpması, iklimsel faktörler, ağır çalışma koşulları vb.leridir. Mevsimlik tarım işçiliğinde barınma-yaşam koşullarının ağırlığından dolayı çok sayıda iş kazası olmaktadır. Bunların görünürlüğü hakkında "Mevsimlik Tarım İşçilerinin Çalışma ve Barınma Koşullarını İzleme" birimlerinin oluşturulması önemlidir. Bunlar kamuda yer alarak her ilde alt birimler oluşturulabilir ve mevsimlik tarım işçilerinin yaşadıkları, karşı karşıya oldukları iş kazaları ile ilgili raporlar oluşturur ve bunları ilgili birimlere ulaştırırlar. Bunun yanı sıra mevsimlik tarım işçilerinin örgütlenmelerine katkıda bulunarak seslerinin daha fazla duyurulması sağlanabilir ve STK'lar da bu konuda önemli roller üstlenebilir. Aslında Türkiye İş Kurumu il müdürlükleri bu konuda önemli roller üstlenebilir fakat bu konudaki görevlerini ne kadar yerine getirdikleri öncelikle tartışılmalıdır. 
Gülçubuk, B. (2017). 6331 Sayılı Tarımda İş Sağlığı Ve Güvenliği Kanunu tarımda çalışanlar için bir şey ifade eder mi? International Journal of Social Sciences and Education Research, 3(2), 573-582.

Mevsimlik gezici tarım işçileri açısından en önemli sorunlardan birisi barınmadır. İşçiler gittikleri yerde kendileri uygun yerler arayıp çadırlarını kurup barınmaya çalışıyorlar. Genelde de buralarda elektrik, su, kanalizasyon vd. altyapı hizmetleri yoktur. Yasa bu konuda tarım aracisına ve işverene önemli görevler yüklemesine rağmen tarım aracılarının neredeyse tamamının kayıt dışı olması ve işverenin de duyarlı olmaması nedeniyle işçiler kendi kaderleri ile baş başa kalmaktadır. Oysa geçici konutlar yapılabilir, kırsalda boş olan konutlar değerlendirilebilir, altyapı hizmeti götürülebilir. Fakat on y1llardır konuşulduğu halde, çok da değişen bir şey yok.

Hangi biçimde olursa olsun tarım işçiliğinde güneş altında çalışmaktan, temel hizmetlere erişememeden ve barınma yerlerinin uygunsuzluğundan dolayı birçok rahatsızlık, meslek hastalığ ortaya çıkabilmektedir. Bunlar bel hastalıkları, eklem hastalıkları, astım, fiziksel gelişim yetersizliği, güneş çarpması, akrep-yılan zehirlemesi vd. biçimlerde ortaya çıkmaktadır. Burada rahatlıkla şu saptamada bulunulabilir; tarım işçileri için işçi sağlığı ve güvenliği tedbirleri alınmamaktır.

Tarım işçiliğinde çalışma saatleri uzundur. Bunu denetleyen de yoktur. Çalışma saatleri işe ve ücret durumuna göre değişmekle birlikte, sabah 6-7'den akşam 18-19'a kadar uzayabilmektedir. Yani günde 12-14 saati bulan çalışma saatleri söz konusu olabilmektedir. Hafta sonu dinlenmesi veya ara verme durumu iş olduğu sürece pek geçerli değil.

2013 yılında mevsimlik tarım işçilerinden 198 kişi iş cinayetlerinde hayatını kaybetti. Bunların 101'i trafik kazalarında hayatını kaybetti. Bu cinayetleri durdurmak gerekiyor, peki bunun için ne yapılmalı?

- Kamu birimlerinin daha duyarlı olması gerekir.

- Yasaların varlığı değil uygulanmasına özen gösterilmelidir.

- Kamyon ve traktör ile ulaşım kesinlikle yasaklanmalıdır.

- Araçlara kapasitesinden fazla birey bindirilmemelidir.

- Tarım aracılığı kayıt altına alınmalı ve sürekli yenilenmelidir.

- İşverenlerin sorumluluklarını yerine getirmeleri 1srarla takip edilmelidir.

- İllerde Türkiye İş Kurumu Müdürlüklerinin hassasiyetleri artmalıdır.

- Kayıt altına alınarak sosyal güvenceye kavuşturma sağlanmalıdır.

- İşçiler açısından etkin örgütlenmeye gidilmelidir.

- Çalışma yerlerinde acil vakalar için mobil sağlık hizmetleri sunulmalıdır.

- Çocuk işçi çalıştırmanın önüne geçilmelidir.

- Dezavantajlı konumdaki bireylerin çalıştırılmamasına özen gösterilmelidir.

- İş sağlığı ve iş güvenliği konusunda eğitimler verilmeli ve bu konularda tarım aracıları ve işverenlerin sorumluluklarını yerine getirmeleri takip edilmelidir.

- Tarımsal ilaç atıkları konusunda hassas davranılmalıdır.

- Akrep, yılan sokmalarına karşı ilk yardım eğitimleri verilmelidir.

- Uluslararası sözleşmelere uyulmalıdır.

- Herkesin duyarlı ve ilgili olmasının bir insanlık görevi olduğu unutulmamalıdır. 
Gülçubuk, B. (2017). Does Act No 6331 on occupational health and safety make impacts on agriculture?

International Journal of Social Sciences and Education Research, 3(2), 573-582.

\section{Sonuç yerine: Tarımda çalışanlar için İş Sağlığı ve Güvenliği ne ifade etmeli, nasıl olmalı?}

Tarım sektöründe çalışan kesim Türk sosyal güvenlik sistemine entegre edilmeye çalışılan en son gruptur. Ülkemizde tarım sektöründe çalışanlara yönelik özel kanuni düzenlemeler 1984 y1lında yapılmıştır. Söz konusu kanuni düzenlemeler tarımda çalışanların maddi yönden özel durumlarını göz önünde bulundurmuş, sosyal güvenliğe dâhil olabilmenin şartlarını diğer çalışanlara göre daha hafif tutmuştur. Bu durum 2008 yılına kadar devam etmiştir. 2008 yılından sonra ise ülkemizin tarımsal gelişme bakımından önemli mesafe kat ettiği ve tarımda çalışanların gelir seviyelerinde artışlar yaşandığ çalışanlarına da norm ve standart birliği gereği aynı hükümler uygulanmaya başlanmıştır. Ancak burada da tam değil, kademeli bir geçiş sistemi öngörülmüştür. Belirtilen kademeli geçişin sonlanacağı yıl ise 2023 olarak öngörülmüştür. Diğer bir deyişle 2023 yılına gelindiğinde diğer çalışanların tabi oldukları sosyal güvenlik hak ve yükümlülükler tarımda çalışanlar için de farklılık göstermeden geçerli olacaktır. Bunun en bariz örneği prim ödeme gün sayısında görülmektedir. 2008 yılına kadar 15 gün üzerinden prim ödeyen tarım çalışanları 2009 yılında 16 gün üzerinden ve sonraki yıllarda birer gün artırılmak suretiyle primlerini ödemek durumundalar.2012 yılı içerisinde ise 19 gün üzerinden prim ödenmektedir. Her yıl için bir gün artırma işlemi sonucunda 2023 y1lına gelindiğinde 30 gün üzerinden prim ödenmiş olacak ve sonraki yıllarda da bu şekilde devam edecektir (SGK 2013).

Ülkemizin en yoksul sınıflarından bir tanesi olan çiftçilerin primli rejim çerçevesinde sağlanan sosyal güvenliğinde iki temel sorun bulunmaktadır. Bunlardan bir tanesi çiftçilerin Bağ-Kur'a kayıtlı olmadan çalışmaları, diğeri ise sigorta prim ödeme kabiliyetlerinin düşüklügüüdür. Çiftçilerde kayıt dışı çalışma yaygındır. Tarım sektöründe sosyal güvencesiz çalışma yaygındır. Tarımda kayıt dışı çalışmanın pek çok nedeni bulunmaktadır. Bunların başında çiftçilerin elde ettiği düşük gelirin prim ödemeye yetmemesi gösterilebilir. Gerçekten de çiftçilerin \%55'inin y1llık asgari ücretin altında tarım geliri elde ettiği göz önüne alındığında kişilerin öncelikleri prim ödemekten önce günlük geçimlerini sağlamak olmaktadır. Tarımda kayıt dışı çalışmanın nedenlerinden bir tanesi gelir yetersizliği ve yoksulluk olarak görülebilir. Bununla birlikte yeterli tarım gelir elde ettiği halde prim ödemekten kaçınan önemli bir kesiminde olduğu gözlerden kaçırılmamal1dır. Bazı çiftçilerin ve ailelerinin sağlık güvencelerini vergilerle finanse edilen yeşil kart yoluyla sağlamaları Bağ-Kur'a kayıtlı olma gereğini kısmen ortadan kaldırmaktadır. Gelir seviyesi yeterli olduğu halde Bağ-Kur'a kayıtlı olmamanın ana nedenlerinden birisi de çiftçilerin eğitim seviyelerinin düşüklügüdür. Sosyal güvenlik bilincinin düşüklüğü, sigortalı olma ile ilgili işlemlerin karışıklığı gelir yeterli olsa bile kayıt dışı çalışmaya yol açabilmektedir.

Sosyal güvenlik sisteminde nüfusun tamamını kapsayan, adil, güvenli, dengeli ve mali açıdan sürdürülebilir bir yapıya kavuşturulması amaçlanmalıdır. Sosyal sigorta sisteminin aktif-pasif oranının düşüklüğ̈̈, nüfusun giderek yaşlanması ve kayıt dışı istihdamın yaygınlığı sistemin mali sürdürülebilirliğini olumsuz yönde etkilemektedir. Ayrıca kayıt dışılık nedeniyle çalışanlar emeklilik dönemi güvencesinden mahrum kalmaktadır. Sosyal güvenlik sisteminin yaşadığı sorunların çözümüne yönelik yeniden yapılanma, Türkiye'de toplumsal yapı ve çalışma yaşamının temel sorun alanları ile birlikte, bütünsel olarak değerlendirildiğinde ancak işlevsel olacaktır.

Kırsal alanın sosyo ekonomik yapısı kentsel alandan farklıdır. Kırsalda ana geçim kaynağı tarımsal faaliyetlerdir. Tarımsal faaliyetler ise küçük ve çok parçalı arazilerde yapılmakta dolayısıyla sermaye birikimi yeterli olmayan ekonomik anlamda karlı olmayan geçimlik işletmelerde 
Gülçubuk, B. (2017). 6331 Sayılı Tarımda İş Sağlığı Ve Güvenliği Kanunu tarımda çalışanlar için bir şey ifade eder mi? International Journal of Social Sciences and Education Research, 3(2), 573-582.

gelir düşük olmaktadır. Diğer yandan eğitim düzeyi de kırsalda düşüktür. Bu durum düzenli olmayan düşük gelir ile bu kesimin sosyal güvenlik kapsamına girmesinde sorunlar yaşamasına neden olmaktadır. Özellikle, prime esas günlük kazanç olarak belirlenen sınırın altında kalan kesim, 5510 sayılı Kanunun öngördüğü sosyal güvenlik uygulamalarından tam anlamıyla yararlanamamaktadır. Yapılan düzenlemeler kapsamında, kamu sosyal güvenlik sistemi cazibesini yitirmekte ve refah rejiminde piyasanın rolü genişlemektedir. Artan işsizlik ve yoksulluk karşısında sosyal korumaya olan gereksinim artarken; sosyal güvenlik sisteminin piyasalaşma eğilimi ile sosyal olan özünün erimesi ve bireyin kendi kaderi ile baş başa bırakılması gibi bir durum ortaya çıkabilmektedir.

2012 yılında yayınlanan 6331 sayılı "İş Sağlığı ve Güvenliği Kanunu” çalışan sayısı bir ve daha fazla olmak üzere tüm sektörleri kapsamaktadır. Böylelikle tarım, orman ve su ürünleri gibi iç içe geçmiş sektörlere de hitap edilmeye başlanmıştır. Ancak bu kanunun tarımsal kesime uygulanmasında önemli zorluklar söz konusudur. Yürürlükteki kanun sigortalı çalışanların uğradığı tüm iş kazalarının Sosyal Güvenlik Kurumu'na raporlanması ve kolluk kuvvetlerine bildirilmesi sorumluluğunu işverene vermiştir. Oysa daha önce de belirtildiği gibi özellikle kendi hesabına çalışanların çok az bir kısmı sigorta kapsamındadır. Herhangi bir kaydı olmayan çalışanların uğradığı kazaların nasıl tanımlanacağı belli değildir. Bunun yanı sıra bazı çiftçilerin korku ya da çeşitli nedenlerle geçirdiği kaza hakkında yasal kuruluşlara bildirimde bulunmadığı, sorunu kendi başına ya da aile içinde çözmeye çalıştığı da bilinen bir gerçektir (Öz, 2005). Söz konusu durum, bu sektörle ilgili sağlıklı bir veri tabanı oluşturulmasının önündeki en büyük engellerden biri olarak karşımıza çıkmaktadır. 6331 sayılı kanun iş yerlerini, çok tehlikeli, tehlikeli ve az tehlikeli olmak üzere üç ana tehlike sınıfına ayırmaktadır. Tarımsal üretim bir bütün olarak tehlikeli işler sınıfında yer almaktadır. Gerek bitkisel üretim gerekse hayvansal üretim kapsamında gerçekleştirilen neredeyse tüm faaliyetlerin tehlikeli olarak tanımlanmasına rağmen risklerin giderilmesi ve gereken önlemlerin alınması için kanunun getirdiği yükümlülüklerin hiçbirinin uygulanması mümkün değildir. Zira "çalışan istihdam etmeksizin kendi nam ve hesabına mal ve hizmet üretimi yapanlar" kanun kapsamı dışında bırakılmıştır. İş Sağlığı ve Güvenliği Kanunu, tehlikeli ve çok tehlikeli işlerde çalışan kişilerin mesleki eğitim almasını zorunlu kılmaktadır (Anonim, 2013). Tarım bir bütün halinde tehlikeli bir iş olarak kabul edilmesine rağmen söz konusu eğitim kapsamına da alınmamaktadır. Burada şu söylenebilir; mevcut yasal düzenlemeler ile tarım sektöründe yaşanan kazaların ve can kayıplarının önüne geçilmesi, daha güvenli bir çalışma ortamı sağlanması ve denetlenmesinin olanaksız olduğu söylenebilir. Bu nedenle sektörün kendine özgü koşulları dikkate alınarak ayrı bir yasa çerçevesinde değerlendirilmesi gerekmektedir. Öte yandan sadece yasal düzenlemelerle tarımda yaşanan kazaların önüne geçilebileceğini ve sağlıklı çalışma koşullarının oluşturulabileceğini düşünmek yanıltıcı olacaktır.

Türkiye'nin ekonomik, sosyal ve siyasi alanlarda ilerlemesi toplumda çalışan herkesi sağlıklı, güvenli işe sahip olması ile ve tarımda, sanayi ve hizmetlerde hak ettiği yere ulaşmasıyla doğru orantılıdır. Tarımda çalışan nüfusun fazlalığı, bu alanda ele alınması gereken bir diğer önemli husus olarak belirmektedir. Çünkü bu nüfusun çok büyük bir çoğunluğu sosyal güvenlikten yoksun ve kayıt dışı çalışan nüfus olup, en zor koşullarda çalışmaktadır. Üretim süreçlerine özellikle emek-yoğun çalışma açısından yoğun katılan tarım çalışanları kayıt dışılıktan ve sosyal güvenlik uygulamalarından yoksun olmalarından dolayı çalışma hayatında bir çok risk ile karşı karşıyadır. Bunu önlemeye yönelik önlemlerin alınması önemlidir ama önce çalışanların kayıtlılığı gerekiyor. Burada her şeyden önce çalışanların çalışma koşulları iyileştirilmeli ve sosyal güvenlik sis- 
temine dâhil olabilecekleri önlemler alınmalıdır. Ancak bunlar olursa iş sağlı̆̆ 1 ve güvenliği tarımda çalışanlar için de bir şeyler ifade eder. Yoksa sadece belirli kesimi kapsayan ve dışlayıcı bir düzenleme olarak kalır ve tarımda çalışanlar hep dezavantajlı konumda kalır. Türkiye'de tarımın ülke ekonomisine 17-18 milyar dolarlık ihracat, 56 milyar dolarlık katma değer, 6 milyona yakın istihdam yaratarak büyük katkı yaptığını dikkate alırsak, Tarımda İş Sağlı̆̆ı ve Güvenliği Kanunu'nun uygulamada karşılık bulması için kırsalda yaşayanların refahtan ve kalkınmadan pay alması ve bunu hissetmesi gerekiyor. Bu olursa Kanun geçerliliğini ve yaygınlığını kazanacaktır.

\section{Kaynakça}

Alper., Değer, Ç., Sayan, S. (2012). "2050'ye DoğruNüfus Bilim ve Yönetim: Sosyal Güvenlik (Emeklilik) Sistemine Bakış". Yayın No: TÜSİAD-T/2012-11/535, 2012, İstanbul.

Anonim, (2013). Tehlikeli ve Çok Tehlikeli Sınıfta Yer Alan İşlerde Çalıştırılacakların Mesleki Eğitimlerine Dair Yönetmelik, Resmi Gazete, 13.07.2013, Sayl: 28706, Ankara.

Çelik, H. ve Ark. (2015). “Tarımda İşücü Kullanımı Ve Sosyal Güvenlik”. Türkiye Ziraat Mühendisliği VIII. Teknik Kongresi, 12-16.Ocak.2015. Ankara

Işın, F., Keskin, G., Kılıç, M., Türkekul, B., Ateş, H.Ç., “Türkiye'de Tarımsal İşgücü Piyasası ve Sosyal Güvenlik Politikaları”. Ziraat Mühendisleri Odası VII. Teknik Kongre, s. 1-22, Ocak 2010, Ankara.

Gökbayrak, Ş. (2010). “Türkiye'de Sosyal Güvenliğin Dönüşümü”. Çallşma ve Toplum Dergisi, 2010/2, sayfa 141-162.

Gülçubuk, B. ve Arkadaşları (2003).Tarım Kesiminde En Kötü Biçimde Çalışan Çocuk İşçiliği Temel Araştırması (Adana İli-Karataş İlçesinde Pamuk Hasadında Çalışan Çocuklar Örneği), ILO-Ankara (Basılmamış).

Gülçubuk, B. (2003). "Globalization and The Agricultural Labor Market in Turkey". The 6 th Conference of The European Sociological Association, 23-26 September 2003, Murcia-Spain.

Gülçubuk,B. ve Yasan, Z., “İşsizlik Yoksulluk Göç Kıskacında Kırsal Alanda Kadın Emeği".Uluslararası Multidisipliner Kadın Kongresi, 13-16.Ekim.2009, İzmir-TURKEY.

Gülçubuk, B. (2012). "Tarımda Çocuk Emeği Sömürüsü ve Toplumsal Duyarlılık". Çalışma ve Toplum Dergisi. Say1:2012/2 (33), s:75-94.

Öz, E. (2005). “Ege Bölgesi’nde Meydana Gelen Traktör Kazalarının Tarımsal İş Güvenliği Açısından Değerlendirilmesi”., Ege Üniversitesi, Ziraat Fakültesi Dergisi, 42(2, s 191-202.

Yıldırak, N. ve Diğerleri (2003). Türkiye'de Gezici ve Geçici Kadın Tarım İşçilerinin Çalışma ve Yaşam Koşulları ve Sorunları. Tarım-İş Sendikası Yayınları, Ankara.

Yurtlu, N. B. (2015).“'Tarımda İş Güvenliği Ve Sağlı̆̆ı”.Türkiye Ziraat Mühendisliği VIII. Teknik Kongresi, 12-16.Ocak.2015. Ankara

www.csgb.gov.tr

www.ilo.org

www.sgk.gov.tr

www.tarim.gov.tr

www.tuik.gov.tr

www.turkis.org.tr

www.zmo.org.tr 
Gülçubuk, B. (2017). 6331 Sayılı Tarımda İş Sağlığı Ve Güvenliği Kanunu tarımda çalışanlar için bir şey ifade eder mi? International Journal of Social Sciences and Education Research, 3(2), 573-582.

\section{Extended abstract in English}

Agriculture is still one of the most important sectors in Turkey. Those who work in the agricultural sector have various risks and even higher risks than other sectors due to its production circumstances. These risks result from different factors that are specific to agriculture. Some of these factors are: agriculture depends on natural conditions, the importance of seasonality, the density of unpaid family workforce, low education level, and the instability of income. Therefore, social security becomes more important for agricultural sector and those who work in this sector though it is vital for everyone.

Countries pay more attention to food security, agricultural lands and try to find more radical to protect food than they did in the past. Solution is about the effective and responsible use of water, land and energy sources in fact, this way of use will protect them for the future. The question of who will use them is important and determiner. The best answer is "family farm" that will continue to live in rural areas, consider agricultural activity as part of their working culture, is sensitive to nature. Family farm is important for agricultural production sustainability. Farming is one of the effective, active elements for food production in both developed and developing countries. The fact of small scale enterprise, which was shown as a chronic problem for a long period in Turkey, became an advantage now. Turkey has a high potential of agricultural production. About 3/1 of population earns its keep in agriculture and 1 out of 5 workforce works in agriculture. Industrial agricultural materials are used us raw material and agriculture supports the development of industry in Turkey. Inequality in agriculture and food system increases in the world. The way to solve this inequality is the development of agriculture through strengthening agricultural production. This is primarily upon the fact that workers in agriculture are included in the scope of social security

Agricultural sector workers are the last group that social security system tries to integrate in Turkey. There are high risks in some jobs in agricultural production and these risky jobs are classified under the highest risk group jobs. Thus, all measures of occupational health and safety are important as well as vital for agriculture. Act No 6331 on Occupational Health and Safety, which has come into force in 2012, involves all sectors with one and/or more workers. As a result, agriculture, forestry and aquaculture sectors, which are intermingled, have been also addressed. However, there are serious difficulties and obstacles to implement this law in the agricultural sector. The main reasons for these implementation problems are related to informal employment, and high level of women and children workforce. According to Turkish Statistical Institute's workforce statistics for May 2015, total employment level is 46,9\% and employment participant rate is $51,7 \%$. There are $27,772,000$ workers that means 534,000 more workers than the same period of previous year and 0,2 percentage increase that makes $46,9 \%$. Agricultural workers have a high percentage in this employment level since $21,3 \%$ out of $46,9 \%$ belongs to the agricultural sector. On the other hand, again, according to 2015 statistics $80,9 \%$ of the agricultural workers are informally employed. It is $69,7 \%$ for male workers while it increases up to $95 \%$ for female workers. The level of informal employment drops to $21 \%$ in other sectors. This fact reveals that agricultural workers stay out of the social security system and deprived of occupational health and safety. "Act No 6331 on Occupational Health and Safety" does not make impacts on agricultural working conditions? This article will provide workforce statistics in agricultural sector, examine the situation of disadvantageous groups and the level of their official employment rate, and put forward recommendations for making impacts on agricultural sector through Act No 6331 on Occupational Health and Safety. 